\title{
Argonaute 2 RNA Immunoprecipitation Reveals Distinct miRNA Targetomes of Primary Burkitt Lymphoma Tumors and Normal B Cells
}

Agnieszka Dzikiewicz-Krawczyk, ${ }^{* \dagger}$ Arjan Diepstra, ${ }^{*}$ Bea Rutgers, ${ }^{*}$ Gertrud Kortman, ${ }^{*}$ Debora de Jong, ${ }^{*}$ Jasper Koerts, ${ }^{*}$ Marian Bulthuis, ${ }^{*}$ Tineke van der Sluis, ${ }^{*}$ Annika Seitz, ${ }^{*}$ Lydia Visser, ${ }^{*}$ Klaas Kok, ${ }^{\ddagger}$ Joost Kluiver, ${ }^{*}$ and Anke van den Berg*

From the Departments of Pathology and Medical Biology* and Genetics, ${ }^{\ddagger}$ University Medical Center Groningen, University of Groningen, Groningen, the Netherlands; and the Institute of Human Genetics, ${ }^{\dagger}$ Polish Academy of Sciences, Poznan, Poland

\author{
Accepted for publication \\ January 30, 2018. \\ Address correspondence to \\ Anke van den Berg, Ph.D., \\ Department of Pathology and \\ Medical Biology, University \\ Medical Center Groningen, \\ University of Groningen, Han- \\ zeplein 1, 9700 RB Groningen, \\ the Netherlands. E-mail: a.van. \\ den.berg01@umcg.nl.
}

\begin{abstract}
miRNAs are small noncoding RNAs involved in the posttranscriptional regulation of gene expression. Deregulated miRNA levels have been linked to Burkitt lymphoma (BL) pathogenesis. To date, the number of known pathogenesis-related miRNA-target gene interactions is limited. Here, we determined for the first time the miRNA targetomes of primary BL tumors and normal B cells. AG02-RNA immunoprecipitation of two frozen diagnostic BL tissue samples and three $\mathrm{CD}_{1}{ }^{+} \mathrm{B}$-cell samples isolated from routinely removed tonsils showed distinct miRNA targetomes of BL and normal $B$ cells. In contrast to normal B cells, miRNA target genes in BL were enriched for targets of the oncogenic miR-17 to 92 cluster, and were involved mainly in cell cycle and cell death. Immunohistochemistry on BL and tonsil tissues confirmed altered protein levels for two of six selected miRNA targets, in line with the differential AG02-IP enrichment between BL and normal B cells. A comparison of AG02-IP-enriched genes in primary $B L$ cases with $B L$ cell lines indicated that despite a considerable overlap, the miRNA targetomes of BL cell lines show substantial differences with the targetomes of primary BL tumors. In summary, we identified distinct miRNA targetomes of BL and normal B cells, and showed both the necessity and feasibility of studying miRNA-target gene interactions in primary tumors. (Am J Pathol 2018, 188: 1289-1299; https://doi.org/10.1016/j.ajpath.2018.01.018)
\end{abstract}

B-cell non-Hodgkin lymphoma accounts for approximately $90 \%$ of all lymphoid malignancies, with an annual incidence of approximately 19 cases per 100,000 individuals. ${ }^{1}$ Burkitt lymphoma (BL) represents approximately $1 \%$ to $2 \%$ of all lymphoma cases and most frequently affects young children. ${ }^{2}$ It is a homogeneous, aggressive lymphoma subtype originating from germinal center (GC) B cells, with a cell number doubling time of 24 to 48 hours. BL is characterized by a chromosomal translocation between the $M Y C$ gene locus and one of the immunoglobulin heavy or light chain gene loci, which results in overexpression of the MYC oncogene.

miRNAs are short (21 to 23 nucleotides) noncoding RNA molecules that mediate post-transcriptional silencing of their target genes. ${ }^{4}$ miRNA-dependent regulation is crucial in cellular processes such as cell cycle, apoptosis, and proliferation. Several studies have shown deregulated miRNA expression in $\mathrm{BL}$ compared with other B-cell lymphoma subtypes and normal B cells. ${ }^{5-7}$ A number of miRNAs and their target genes have been studied in detail in the context of BL. ${ }^{8-12}$ A global Argonaute 2 (AGO2)-photoactivatable ribonucleoside-enhanced crosslinking and immunoprecipitation approach in BL cell lines showed miRNA target genes involved in the Ras, mitogen-activated protein kinase and phosphatidylinositol 3-kinase-Akt signaling pathways. ${ }^{13}$ However, it remains unknown to what extent these miRNA - mRNA interactions occur in primary BL tumors. Moreover, a direct comparison with the global miRNA targetome of normal B cells to identify genes that have gained or lost regulation by miRNAs during malignant transformation to $\mathrm{BL}$ is missing.

Supported by Pediatric Oncology Foundation Groningen grant SKOG 11-001 (J.K. and A.v.d.B.).

Disclosures: None declared. 
Table 1 Quantitative RT-PCR Primer Sequences

\begin{tabular}{ll}
\hline Name & Sequence \\
\hline CD69 & F: 5'-GTGTGCTGTAATGAATGTGGTCT-3' \\
CD69 & R: 5'-TGAGAATGTGTATTGGCCTGGA-3' \\
MYLIP & F: 5'-AAAGCCAACGGCGAGGAC-3' \\
MYLIP & R: 5'-TCACCTTTGCTACCCGTAAACTG-3' \\
TNFRSF12A & F: 5'-CTCTGAGCCTGACCTTCGTG-3' \\
TNFRSF12A & R: 5'-GTCTCCTCTATGGGGGTGGT-3' \\
CCNE1 & F: 5'-TGCACACAACATACAGACCCA-3' \\
CCNE1 & R: 5'-ACATGGCTTTCTTTGCTCGG-3' \\
DYNLT1 & F: 5'-CTGCGGAGGAGGCTATAGAAA-3' \\
DYNLT1 & R: 5'-GCAGGAACTTGCTGTGTGTAA-3' \\
U6 & F: 5'-TGGAACGATACAGAGAAGATTAGCA-3' \\
U6 & R: 5'-AAAATATGGAACGCTTCACGAATT-3' \\
P0LR2A & F: 5'-CGTACGCACCACGTCCAAT-3' \\
P0LR2A & R: 5'-CAAGAGAGCCAAGTGTCGGTAA-3' \\
\hline
\end{tabular}

$F$, forward; $R$, reverse.

A popular method to study the genes regulated by miRNAs is the RNA immunoprecipitation (RIP) of AGO2 containing RNA-induced silencing complexes. ${ }^{14}$ Subsequent expression analysis using the RNA isolated from the total and immunoprecipitated (IP) fractions allows identification of the transcripts enriched in the IP fraction, representing the miRNA targetome. In this study we performed AGO2 RIP of two primary BL tissue samples and tonsillar B cells of three control subjects. We identified distinct miRNA targetomes of BL cases and normal B cells. miRNA targets identified in BL were enriched in genes involved in the regulation of cell cycle and cell death in BL, highlighting the relevance of miRNAs in BL pathogenesis.

\section{Materials and Methods}

\section{Tissue Samples}

Individual diagnoses of 10 pediatric BL samples were reviewed by an experienced hematopathologist for consistent morphology and immunophenotype according to the World Health Organization classification. ${ }^{15}$ All pediatric BL cases presented with an abdominal mass, were positive for CD10 and negative for BCL2, and carried a MYC translocation. Nine of the BL patients were included in a previous study. ${ }^{12}$

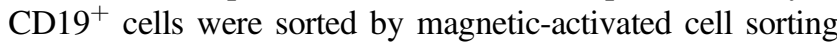
from tonsil tissue samples of three donors between 3 and 9 years old. Briefly, fresh tonsillar cell suspensions were prepared and enriched for CD19 ${ }^{+}$cells using CD19 beads and LS columns (both Miltenyi Biotec, Leiden, The Netherlands). Purity of the CD19 cells was confirmed and the relative fraction of naive, memory, GC, and plasma B cells was determined by fluorescence-activated cell sorting using antibodies against CD19, IgD, and CD38 as described previously. ${ }^{16}$ Patient and control characteristics are presented in Supplemental Tables S1 and S2. The procedures were performed according to the guidelines of the Medical Ethical Committee of the University Medical Center Groningen.

\section{AG02-RIP-Chip}

Immunoprecipitation of $\mathrm{AGO} 2$ containing RNA-induced silencing complexes was performed on 50 tissue sections $(10 \mu \mathrm{m})$ of two fresh-frozen primary BL tumors and three samples of $\mathrm{CD}_{19}{ }^{+} \mathrm{B}$ cells sorted from tonsils. AGO2 IP was performed as described previously. ${ }^{14}$ Briefly, cleared cell lysate was incubated with protein G Sepharose beads (GE Healthcare, Eindhoven, The Netherlands) coated with anti-AGO2 antibody (clone 2E12-1C9; Abnova, Taipei, Taiwan) at $4^{\circ} \mathrm{C}$ for 7 hours. RNA was isolated using Phase Lock Gel Heavy (5 Prime GmbH, Hilden, Germany) and the miRNeasy mini- or microkit (Qiagen, Germantown, MD). RNA from the total (T) and AGO2-IP fractions was analyzed on a custom-designed microarray containing probes for all protein-coding genes and an extensive set of long noncoding RNA (ID 050524; Agilent, Santa Clara, CA). ${ }^{17}$ Labeling and hybridization was performed with 50 to $100 \mathrm{ng}$ of total RNA using the LowInput QuickAmp Labeling kit and Cyanine 5 CTP Dye Pack according to the manufacturer's protocol (Agilent). Data were analyzed using GeneSpring GX version 12.5 (Agilent). Quantile normalization of the signals was performed. Probes not detected in all samples and probes that were inconsistent (>twofold different) in two replicates of the same sample were filtered out. The averaged signals for replicates were used to calculate the IP/T ratios for each probe and for each sample separately. The microarray data have been deposited in Gene Expression Omnibus (http://www.ncbi.nlm.nih.gov/ geo; accession number GSE107325). Probes with a twofold or more IP/T ratio were defined as AGO2-IP-enriched probes and were considered potential miRNA targets.

\section{Quantitative RT-PCR}

cDNA was synthesized from 50 ng RNA using random primers and the Superscript II Reverse Transcriptase Kit (Life Technologies, Bleiswijk, NL). The quantitative PCR was performed with primers specified in Table 1 and SYBR Green Master Mix (Applied Biosystems, Foster City, CA) using an input of $1 \mathrm{ng}$ cDNA in a $10-\mu \mathrm{L}$ volume. A multiplex miRNA-specific cDNA synthesis and quantitative PCR was performed using the TaqMan MicroRNA Reverse Transcription Kit and TaqMan MicroRNA Assays (miR-16a5p, assay ID 000391; miR-92a-3p, assay ID 000431; Applied Biosystems) as described previously. ${ }^{18}$ miRNA levels were normalized to RNU48 (assay ID 001006; Applied Biosystems).

\section{Immunohistochemistry}

Immunohistochemical staining was performed on 3- $\mu \mathrm{m}$ tissue sections of formalin-fixed, paraffin-embedded BL tumor samples and tonsils using routine protocols. Antigen retrieval conditions were as follows: NEDD9 and AKTIP, 15-minute microwave in a $1 \mathrm{mmol} / \mathrm{L}$ EDTA buffer $\mathrm{pH} 8$; TAF8, HDAC5, 
and CCNA2, 15-minute microwave in a $10 \mathrm{mmol} / \mathrm{L}$ Tris/1 mmol/L EDTA buffer pH 9; and KAT7, 7-minute autoclave at $125^{\circ} \mathrm{C}$ in a $1 \mathrm{mmol} / \mathrm{L}$ EDTA buffer $\mathrm{pH}$ 8. Tissue sections were incubated for 1 hour with the following primary antibodies and dilutions: NEDD9, HPA038768, 1:50; AKTIP, HPA046300, 1:500; CCNA2, HPA020626, 1:100; TAF8, HPA31731, 1:50; KAT7, HPA044470, 1:100; and HDAC5, HPA030991, 1:200 (all Atlas Antibodies, Bromma, Sweden). Visualization was performed with diaminobenzidine and staining was scored as negative $(-)$, positive $(+)$, or strong positive $(++)$ by an experienced hematopathologist.

\section{Gene Ontology and Gene Set Enrichment Analysis}

Gene Ontology (GO) analysis was performed for genes AGO2-IP-enriched in both BL cases (831 genes) and for genes AGO2-IP-enriched in at least two of three CD19 ${ }^{+}$ B-cell samples (1141 genes) using DAVID Functional Annotation Tools version 6.7. ${ }^{19,20}$ Preranked Gene Set Enrichment Analysis was performed on average IP/T fold-change values for BL cases and for $\mathrm{CD} 19^{+}$cells. In case of multiple probes targeting one gene, the probe with the highest IP/T value was selected. Gene sets for BioCarta, Kyoto Encyclopedia of Genes and Genomes, and Reactome pathways were downloaded from the Molecular Signatures Database version 6.0. ${ }^{21}$

\section{Statistical Analysis}

To assess whether the percentage of predicted targets of a miRNA was significantly higher among genes enriched in the AGO2-IP fraction as compared with the percentage among all expressed genes, $\chi^{2}$ goodness-of-fit test was applied.

\section{Results}

\section{Primary BL Cases and Normal B Cells Have Distinct miRNA Targetomes}

To determine the miRNA targetomes of primary BL cases and normal B cells, AGO2-RNA immunoprecipitation was performed followed by microarray analysis (AGO2-RIPChip) in two primary BL cases, and three samples of purified $\mathrm{CD} 19^{+} \mathrm{B}$ cells isolated from tonsils (Supplemental Tables S1 and S2). The efficiency of the AGO2-IP procedure was confirmed by the strong enrichment of miRNAs in the IP fraction compared with the total fraction (Figure 1A). A total of 1364 probes (mapping to 1141 protein-coding genes and 72 noncoding genes) that were twofold enriched or more in the AGO2-IP of at least two of three $\mathrm{CD} 19^{+} \mathrm{B}$-cell samples were identified. In the two BL cases, 940 probes (mapping to 831 protein-coding genes and 19 noncoding genes) were consistently twofold or more IP-enriched (Figure 1B and Supplemental Table S3). A total of 626 (67\%) of the 940 AGO2-IP-enriched probes in BL cases also were AGO2-IP-enriched in the B cells. Among 1364 probes, which were AGO2-IP enriched in at least two of three CD19 ${ }^{+}$ B-cell samples, 161 (147 genes) had at least a twofold higher AGO2-IP enrichment in CD19 $9^{+}$B cells compared with BL, and among 940 probes which were AGO2-IP enriched in both BL cases, 165 (159 genes) had at least a twofold higher AGO2-IP enrichment in BL compared with $\mathrm{CD} 19^{+} \mathrm{B}$ cells (Figure 1C).

To confirm the results of the AGO2-RIP-Chip analysis, quantitative RT-PCR was performed for several previously validated miRNA target genes ${ }^{22-26}$ with a high enrichment in the AGO2-IP fraction of BL cases. Levels of CD69, MYLIP, TNFRSF12A, CCNE1, and DYNLT1 were increased in the AGO2-IP fraction compared with the total fraction, in accordance with the array results, whereas levels of the U6 and POLR2A control genes were not increased (Figure 1D). As a further validation, the overlap between the AGO2-IPenriched probes of the two primary BL cases and two BL cell lines that was published previously was determined. ${ }^{12}$ Of 2025 probes enriched in at least one of the BL cases, 996 (49\%) also were AGO2-IP-enriched in at least one of the BL cell lines. On the other hand, of 2450 probes enriched in at least one BL cell line, 1454 (59\%) were not AGO2-IP-enriched in any of the BL cases (Figure 1E).

Next, enrichment in the AGO2-IP fraction of genes predicted to be targeted by miRNAs known to be deregulated in BL was checked. Members of the miR-17 92 cluster known to be upregulated in $\mathrm{BL},{ }^{27,28}$ and $\mathrm{miR}-15 / 16,{ }^{29} \mathrm{miR}-26,{ }^{30} \mathrm{miR}-28,{ }^{8,11}$ miR-29, ${ }^{9}$ miR-150, ${ }^{12,31}$ and miR- $155^{32}$ known to be downregulated in BL compared with normal B cells, were studied. TargetScan-predicted conserved targets (TargetScan Release $7.1^{33}$ ) of miR-29-3p and miR-150-5p were significantly more enriched in the AGO2-IP fraction of $\mathrm{CD} 19^{+} \mathrm{B}$ cells compared with BL cases. Enrichment of predicted targets of miR-26-5p, miR-28-5p, and miR-155-5p also was higher in B cells, albeit not significantly (Figure 1F). Significantly higher enrichment of TargetScan-predicted targets for three of four miRNA seed families of the oncogenic miR-17 to 92 cluster were found in the AGO2-IP fraction of $\mathrm{BL}$ cases compared with $\mathrm{CD} 19^{+} \mathrm{B}$ cells (Figure 1G).

Thus, distinct miRNA targetomes of normal B cells and primary BL cases were identified, and it was shown that despite a considerable overlap, the miRNA targetomes of BL cell lines show substantial differences with the targetomes of primary BL tissue samples.

\section{Cell Cycle and Cell Death Are Main Processes Regulated by miRNAs in $B L$}

Next, it was explored whether miRNA target genes in normal B cells and in BL cases are involved in different biological processes. GO analysis of 831 genes enriched in the AGO2-IP fraction of both BL cases showed significant over-representation $(P<0.05$ after Benjamini-Hochberg correction) of GO terms related to cell cycle, cell death, catabolic processes, and transcription. The 1141 genes enriched in AGO2-IP of at least two of three B-cell samples 
A

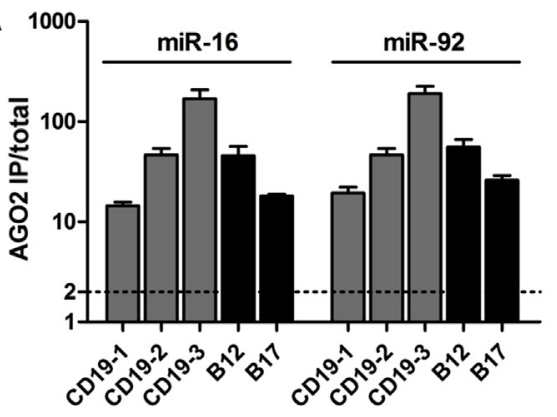

D

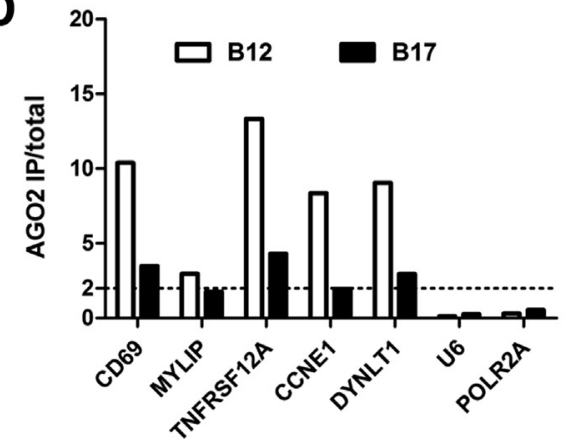

B
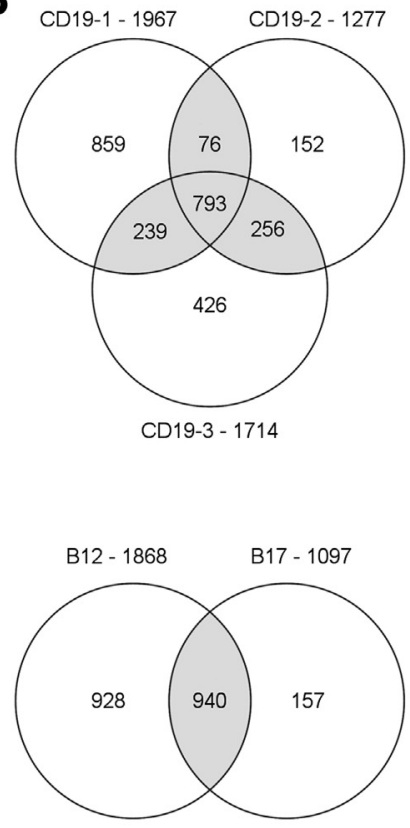

C

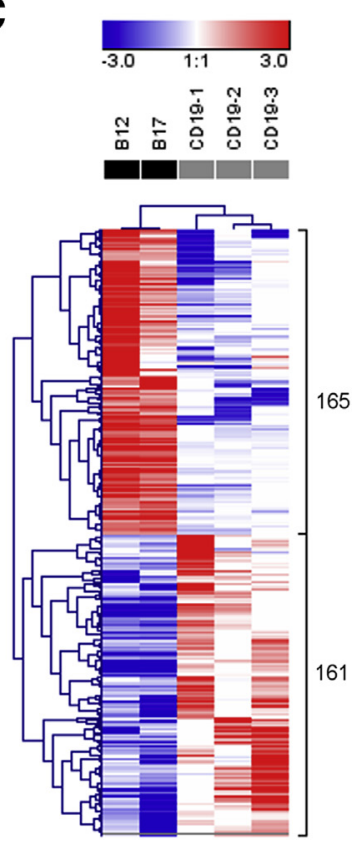

$\mathbf{E}$

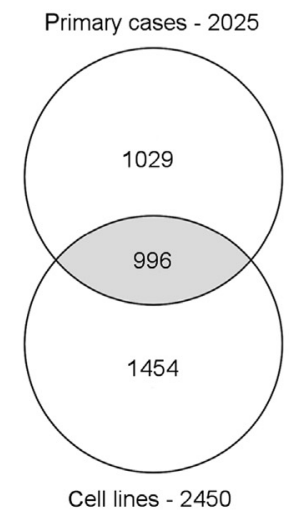

G

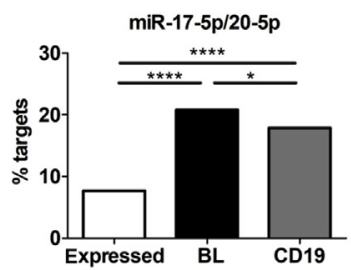

$\mathbf{F}$
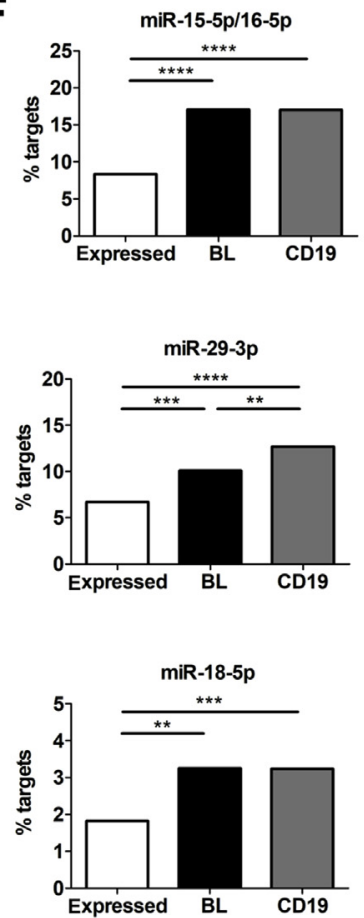
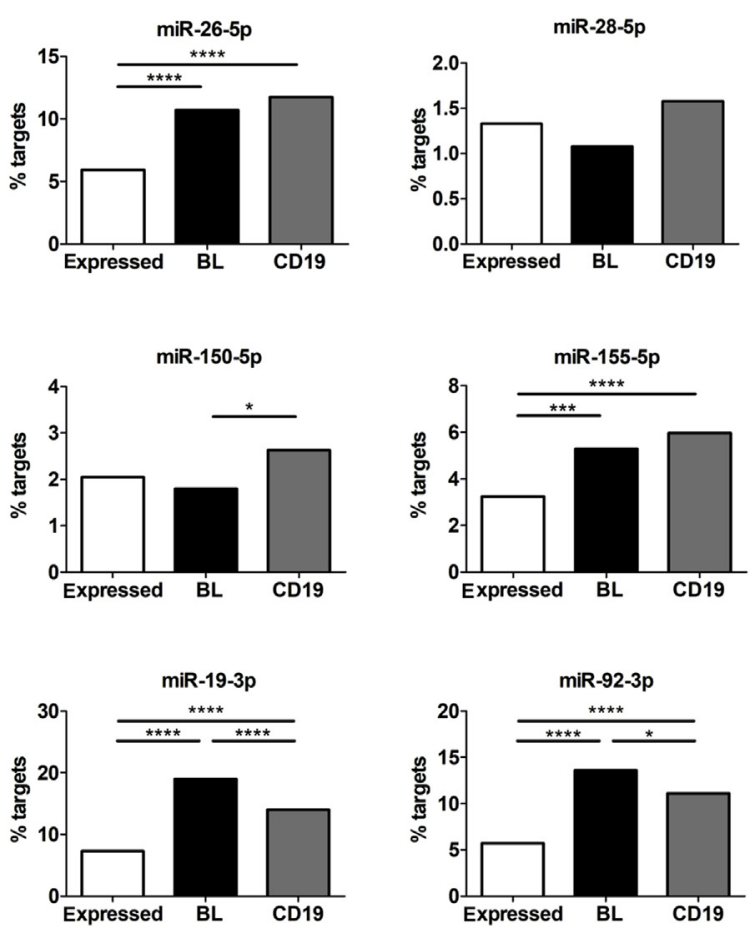

Figure 1 Distinct miRNA targetomes of primary Burkitt lymphoma (BL) cases and CD19+ normal B cells. A: miR-16-5p and miR-92a-3p are strongly enriched in the Argonaute 2-immunoprecipitated (AG02-IP) fraction compared with the total fraction. miRNA levels were determined by quantitative RT-PCR and normalized to RNU48. Dashed line indicates the IP/total (T) ratio cut-off value used to define the AG02-IP-enriched probes. B: 0verlap of AG02IP-enriched probes (IP/T $\geq 2$ ) in $\mathrm{CD}_{1} 9^{+} \mathrm{B}$ cells and BL cases. The number of probes in each sample is indicated. C: Heatmap of IP/T ratios for probes with $\geq$ twofold higher $(n=165)$ or lower $(n=161)$ AG02-IP enrichment in BL cases versus CD19 $\mathrm{B}$ cells. D: AG02-IP enrichment of validated miRNA target genes in BL cases: CD69, MYLIP, TNFRSF12A, CCNE1, and DYNLT1 was confirmed by quantitative RT-PCR. U6 and P0LR2A were not enriched in the AG02-IP fraction and serve as negative control. Fold enrichment was calculated as follows: $2-\Delta C p$, where $\Delta C p=C p$ (AG02-IP) $-C p$ (total fraction). Dashed line indicates the IP/T ratio cut-off value used to define the AG02-IP-enriched probes. E: Overlap of AG02-IP-enriched probes in two primary BL cases with two BL cell lines from our previous study. ${ }^{12}$ Sixty-two percent of probes identified in BL cases also were AG02-IP-enriched in at least one BL cell line. $\mathbf{F}$ and $\mathbf{G}$ : Percentage of TargetScan-predicted target genes of selected miRNAs known to be down-regulated $(\mathbf{F})$ or up-regulated $(\mathbf{G})$ in $B L$, among all expressed genes and among genes enriched in the AG02-IP fraction of both $\mathrm{BL}$ cases or two of three CD19+ samples. ${ }^{*} P<0.05,{ }^{* *} P<0.01,{ }^{* * *} P<0.001$, and ${ }^{* * * * P} P 0.0001$ ( $\chi^{2}$ goodness-of-fit test). Cp, crossing point-PCR-cycle. 
A
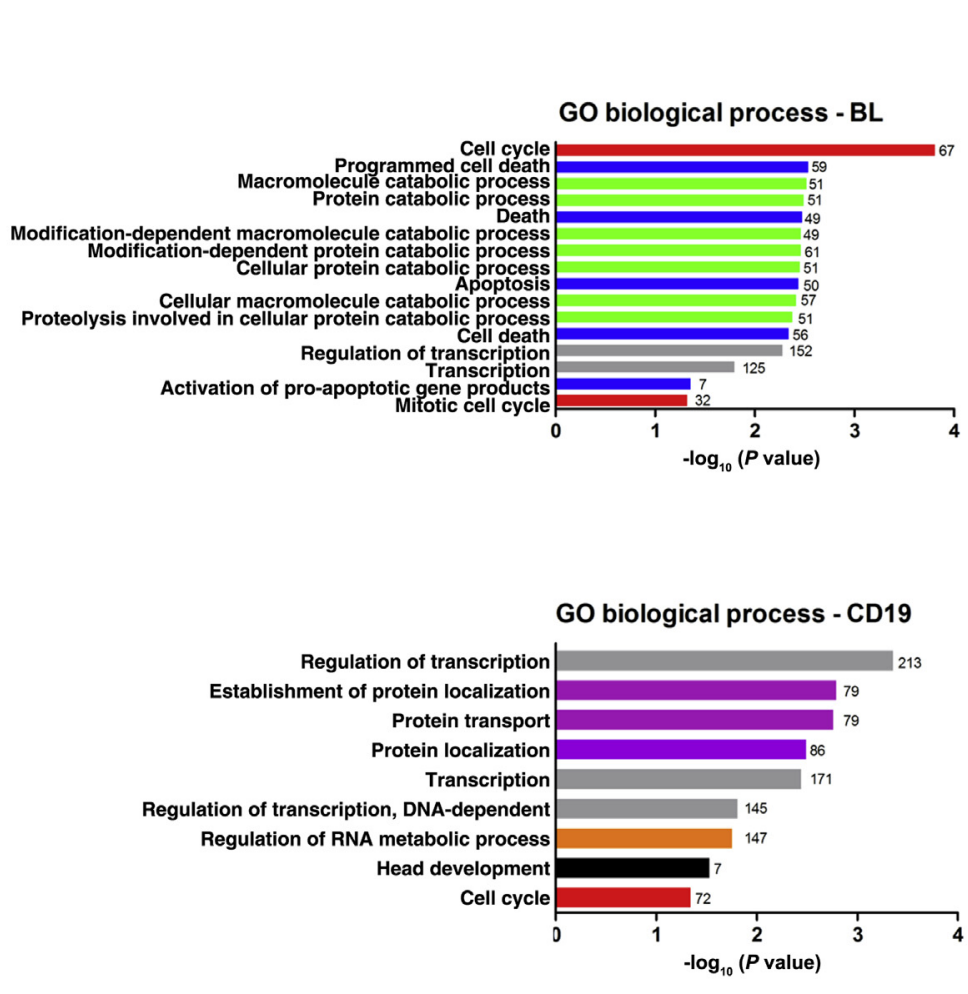

GO biological process - CD19
B

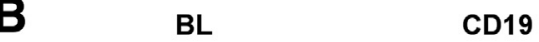

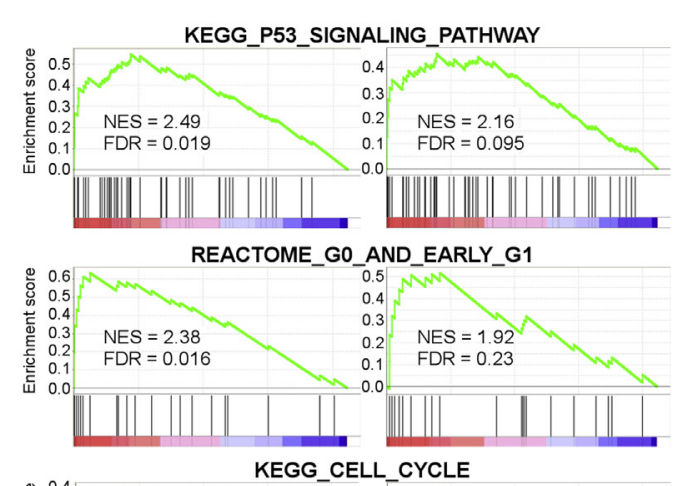
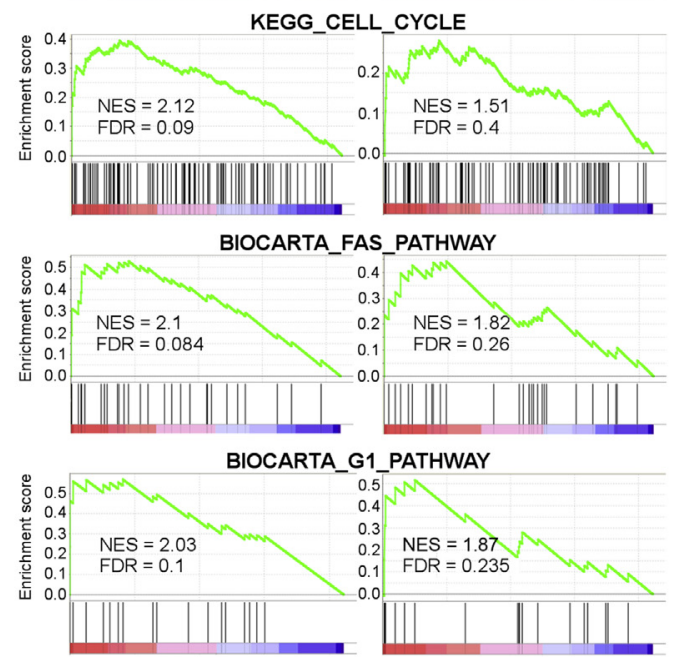

Figure 2 Cell cycle and cell death are the main processes regulated by miRNAs in Burkitt lymphoma (BL). A: Gene Ontology (G0) terms were significantly overrepresented ( $P<0.05$ after Benjamini-Hochberg correction) among genes enriched in the argonaute 2-immunoprecipitated (AG02-IP) fraction of both BL cases (581 of 831 genes with G0 annotation) or in two of three CD19+ samples (802 of 1141 genes with $G 0$ annotation). The number of genes in each category is indicated. B: Enrichment plots of gene sets related to cell cycle and cell death among the top 20 enriched gene sets in BL. Preranked Gene Set Enrichment Analysis was performed on average immunoprecipitated/total fold-change values for BL cases and for CD19 ${ }^{+}$cells with BioCarta, Kyoto Encyclopedia of Genes and Genomes $(\mathrm{KEGG})$, and Reactome pathways gene sets. FDR, false discovery rate; KEGG, Kyoto Encyclopedia of Genes and Genomes; NES, normalized enrichment score.

showed a significant over-representation of GO terms linked to transcription, protein transport and localization, RNA metabolic processes, head development, and cell cycle (Figure 2A). Gene set enrichment analysis for BioCarta, Kyoto Encyclopedia of Genes and Genomes, and Reactome pathways showed five pathways related to cell cycle and cell death enriched in the AGO2-IP fraction of BL cases: the Kyoto Encyclopedia of Genes and Genomes p53 signaling and cell-cycle pathways, the BioCarta Fas and G1 pathways, and the Reactome G0 and early G1 pathway. In CD19+ $\mathrm{B}$ cells these pathways had lower normalized enrichment scores and higher false discovery rate values (Figure 2B and Supplemental Table S4). Thus, miRNA target genes in BL are involved mainly in cell cycle and cell death.

\section{Altered mRNA and Protein Levels of Selected miRNA Target Genes}

miRNAs affect protein levels of their target genes by inhibition of translation or by promoting transcript degradation. We hypothesized that genes that are differentially
AGO2-IP-enriched between BL and normal B cells are more likely to show changes in mRNA and protein expression than those that do not show changes in AGO2-IP enrichment. Indeed, among the 159 genes showing at least a twofold higher AGO2-IP enrichment in BL compared with $\mathrm{CD} 19^{+}$cells, 46 genes $(28.9 \%)$ had lower transcript levels in BL compared with $\mathrm{CD} 19^{+}$cells (fold change $\leq-1.5$ ). This percentage was significantly higher than the $19.8 \%$ genes with lower expression in BL among all expressed genes $\left(P=0.0027, \chi^{2}\right.$ test). Conversely, among 147 genes with at least a twofold higher AGO2-IP enrichment in normal B cell samples as compared with BL, 95 genes $(64.6 \%)$ had lower expression levels in $\mathrm{CD} 19^{+}$cells compared with BL (fold change $\leq-1.5$ ). Again, this was significantly more than the $27.8 \%$ of genes with lower expression in $\mathrm{CD} 19^{+} \mathrm{B}$ cells among all expressed genes $\left(P<0.0001, \chi^{2}\right.$ test) (Figure $\left.3 \mathrm{~A}\right)$.

To confirm altered protein expression, BL tissue samples and tonsils as normal tissue were stained. Based on the availability of immunohistochemistry (IHC)-validated antibodies, six proteins encoded by genes belonging to the 
A

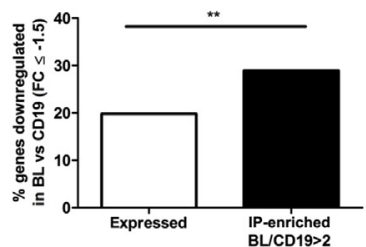

B

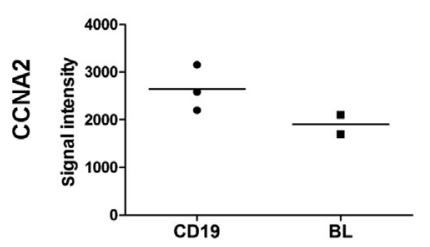

C

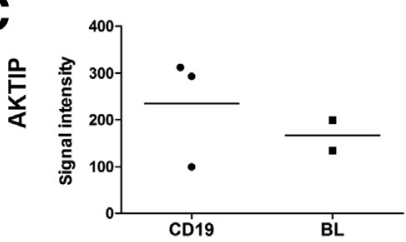

D

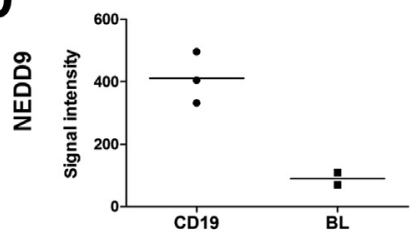

E

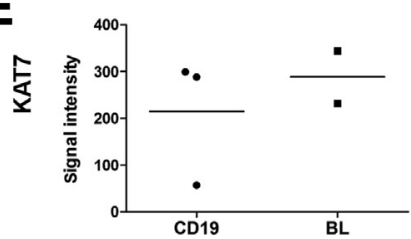

$\mathbf{F}$
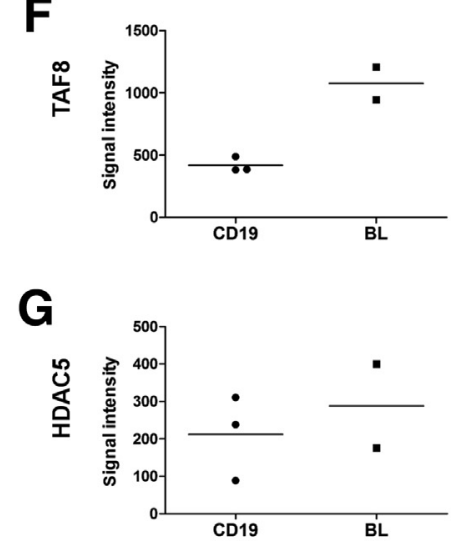

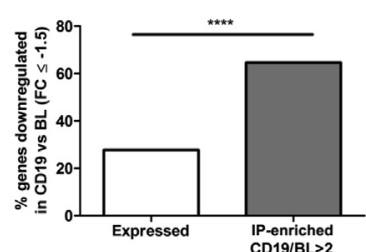

AGO2-IP enrichment
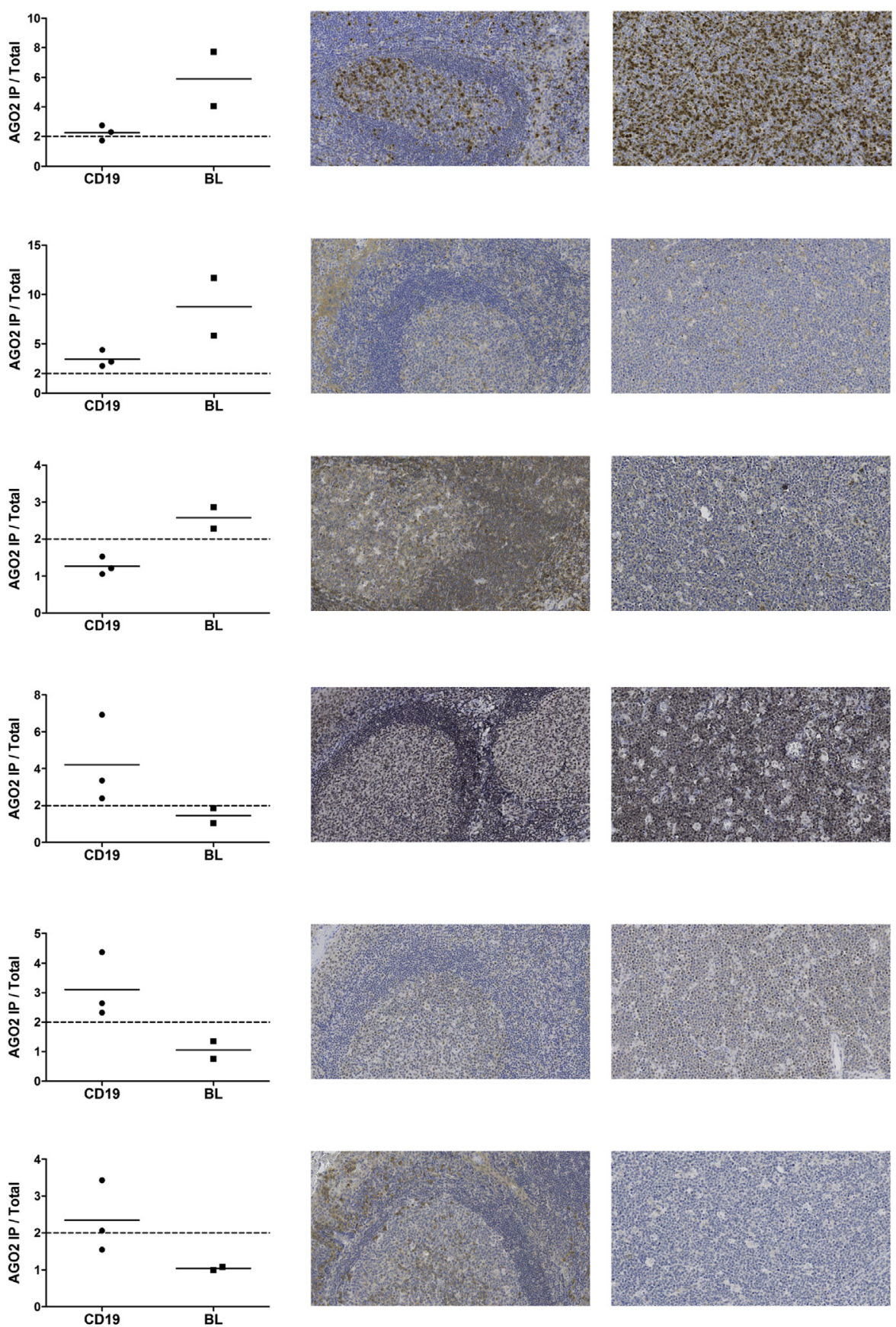

BL
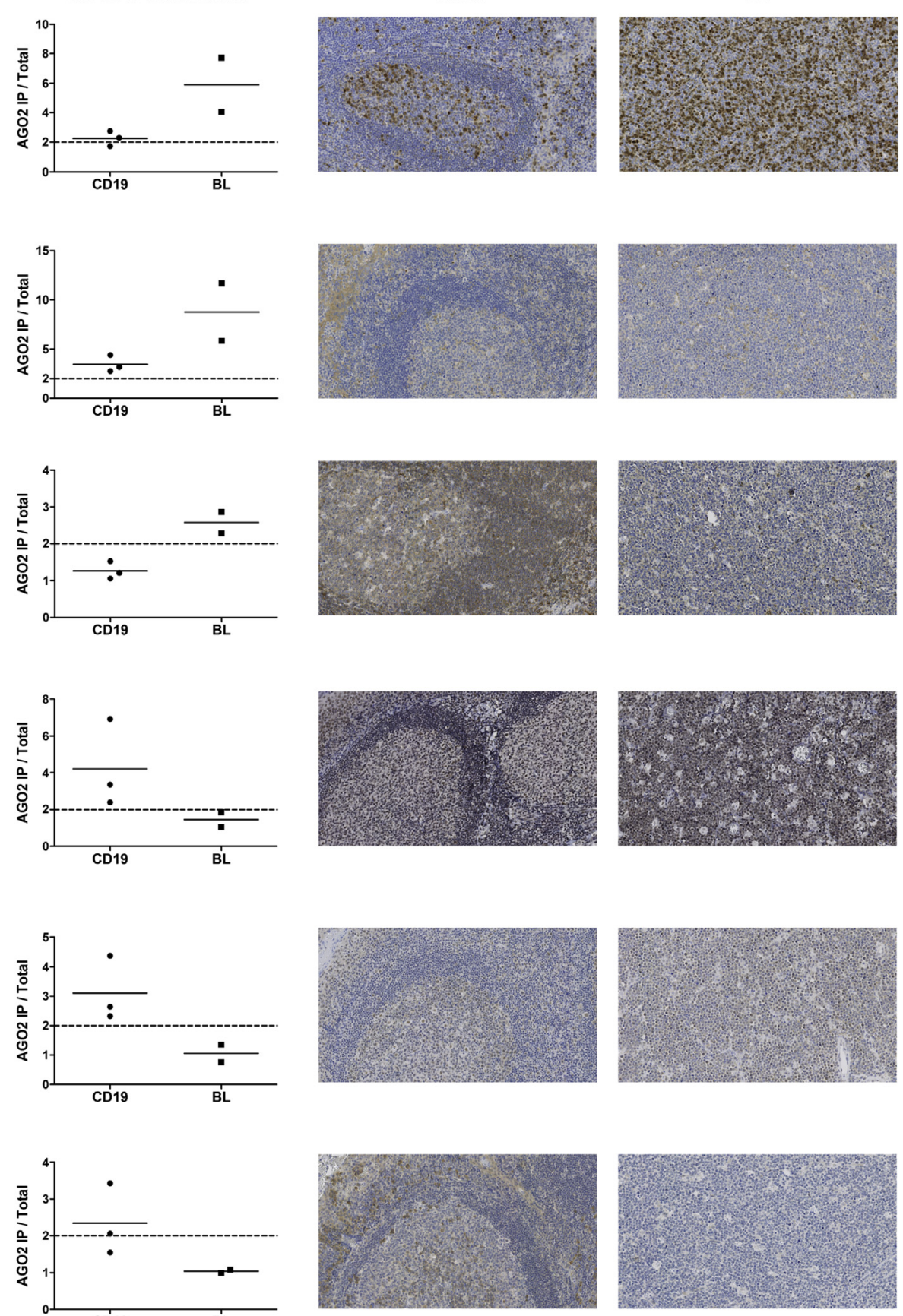

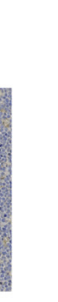

Figure 3 Altered mRNA and protein levels of selected miRNA target genes. A: Percentage of genes down-regulated (fold change $\leq-1.5)$ in Burkitt lymphoma (BL) versus $\mathrm{CD} 19^{+} \mathrm{B}$ cells or in $\mathrm{CD} 19^{+} \mathrm{B}$ cells versus $\mathrm{BL}$ among all expressed genes and genes with $\geq$ twofold higher argonaute 2-immunoprecipitated (AG02-IP) enrichment B-G: Expression, AG02-IP enrichment, and immunohistochemistry (IHC) of selected miRNA target genes. From left: mRNA expression level, AG02-IP enrichment, and representative IHC images of tonsillar germinal center (GC) and BL cases. Horizontal lines indicate mean values; dashed lines, the IP/T ratio cut-off value used to define the AG02-IP-enriched probes. B-G: CCNA2 (B), AKTIP (C), NEDD9 (D), KAT7 (E), TAF8 $(\mathbf{F})$, and $\operatorname{HDAC5}(\mathbf{G}) .{ }^{* *} P<0.01,{ }^{* * *} P<0.0001$ ( $\chi^{2}$ goodness-of-fit test). Original magnification, $\times 200(\mathbf{B}-\mathbf{G})$. 
Table 2 Genes Belonging to the Top Three Over-Represented Gene Ontology Terms in BL AG02-IP, and Whose AG02-IP Enrichment Is at Least Two Times Higher in BL Cases Compared with CD19+ $\mathrm{B}$ Cells

\begin{tabular}{|c|c|c|c|c|c|c|}
\hline Gene & $\mathrm{IP} / \mathrm{T}$ in $\mathrm{BL}$ & $\mathrm{IP} / \mathrm{T}$ in $\mathrm{CD} 19$ & BL/CD19 & Cell cycle & Cell death & Catabolic process \\
\hline GATA6 & 6.16 & 1.00 & 6.17 & & $x$ & \\
\hline$D C P S$ & 6.68 & 1.89 & 3.53 & & & $x$ \\
\hline TGFB1I1 & 3.32 & 1.06 & 3.13 & & & $x$ \\
\hline PDCD10 & 3.65 & 1.16 & 3.13 & & $x$ & \\
\hline MARCH9 & 5.58 & 1.79 & 3.12 & & & $x$ \\
\hline UBE2Q2 & 4.13 & 1.39 & 2.98 & & & $x$ \\
\hline FAM83D & 19.78 & 7.20 & 2.75 & $x$ & & \\
\hline$E R H$ & 2.88 & 1.05 & 2.74 & $x$ & & \\
\hline CCNA2 & 5.90 & 2.25 & 2.62 & $x$ & & \\
\hline AKTIP & 8.77 & 3.44 & 2.55 & & $\mathbf{x}$ & \\
\hline$R H O B$ & 3.74 & 1.56 & 2.40 & & $x$ & \\
\hline FAS & 3.58 & 1.53 & 2.33 & & $x$ & \\
\hline CCNE1 & 12.42 & 5.58 & 2.23 & $x$ & & \\
\hline PSMB1 & 3.13 & 1.42 & 2.20 & $x$ & & $x$ \\
\hline TUSC2 & 4.99 & 2.31 & 2.17 & $x$ & & $x$ \\
\hline CDKN1C & 3.10 & 1.43 & 2.16 & $x$ & & \\
\hline HERC4 & 4.25 & 2.00 & 2.13 & & & $x$ \\
\hline МАРЗК8 & 4.75 & 2.25 & 2.11 & $x$ & & \\
\hline BOD1 & 18.56 & 8.81 & 2.11 & $x$ & & \\
\hline TAOK2 & 3.45 & 1.64 & 2.11 & & $x$ & \\
\hline MARCH3 & 7.28 & 3.47 & 2.10 & & & $x$ \\
\hline
\end{tabular}

Genes selected for immunohistochemistry validation are shown in bold.

AG02-IP, argonaute 2-immunoprecipitated; BL/CD19, ratio of immunoprecipitated/total in Burkitt lymphoma to immunoprecipitated/total in CD19; IP/T, mean immunoprecipitated/total ratio.

top three enriched GO terms and showing at least a twofold higher AGO2-IP enrichment in BL cases compared with $\mathrm{CD}^{+}{ }^{+}$cells (CCNA2, AKTIP, and NEDD9) (Table 2) and vice versa (KAT7, TAF8, and HDAC5) (Table 3) were selected. These genes are predicted to be targeted by several miRNAs, including miRNAs deregulated in BL (Supplemental Figure S1). CCNA2, AKTIP, and NEDD9 showed higher AGO2-IP enrichment in BL cases accompanied by lower transcript levels. Based on the increased miRNA-mediated repression, these genes are expected to have lower protein levels in BL cases compared with $\mathrm{CD}^{+}{ }^{+} \mathrm{B}$ cells. CCNA2 staining was strongly positive in both BL and GCB cells (Figure 3B and Table 4). AKTIP staining was negative for both BL and GCB cells, although some macrophages and dendritic cells within the germinal centers were positive (Figure 3C and Table 4). In line with much lower NEDD9 transcript levels in BL compared with $\mathrm{CD} 19^{+} \mathrm{B}$ cells and the stronger IP enrichment in BL, six of nine BL cases were negative and three were positive, whereas GCB cells in all four tonsil samples were positive or strongly positive for NEDD9 (Figure 3D and Table 4). KAT7, TAF8, and HDAC5 were AGO2-IP-enriched in $\mathrm{CD}{ }^{+} \mathrm{B}$ cells but not in BL cases and the transcript levels of all three genes were higher in BL cases. Although GCB cells were consistently positive for KAT7 protein in the tonsil samples, seven of nine BL samples showed a much stronger staining pattern and two showed a staining intensity that was more similar to GCB cells (Figure 3E and Table 4). This is in line with the stronger IP enrichment of KAT7 in $\mathrm{CD}^{+}{ }^{+} \mathrm{B}$ cells compared with BL. TAF8 staining was positive in both BL and GCB cells (Figure 3F and Table 4). Both GCB cells and BL cases were negative for HDAC5, whereas plasma cells within and outside the GCs were strongly positive (Figure $3 \mathrm{G}$ and Table 4). Thus, lower NEDD9 protein levels were shown in BL consistent with the stronger AGO2-IP enrichment of its transcript in BL cases, 
Table 3 Genes Belonging to the Top Three Overrepresented Gene Ontology Terms in CD19 AG02-IP, and Whose AG02-IP Enrichment Is at Least Two Times Higher in $\mathrm{CD} 19^{+}$B Cells Compared with BL Cases

\begin{tabular}{|c|c|c|c|c|c|c|}
\hline Gene & $\mathrm{IP} / \mathrm{T}$ in $\mathrm{BL}$ & $\mathrm{IP} / \mathrm{T}$ in $\mathrm{CD} 19$ & CD19/BL & Transcription & Protein transport & RNA metabolism \\
\hline$C B Y 1$ & 4.56 & 16.52 & 3.62 & $x$ & $x$ & $x$ \\
\hline MBTD1 & 1.44 & 4.70 & 3.26 & $x$ & & \\
\hline GABARAP & 1.05 & 3.26 & 3.11 & & $x$ & \\
\hline PDE\&A & 1.31 & 3.86 & 2.95 & $x$ & & $x$ \\
\hline SNUPN & 1.04 & 3.05 & 2.93 & & $x$ & \\
\hline KAT7 & 1.47 & 4.22 & 2.88 & $x$ & & $x$ \\
\hline TAF8 & 1.23 & 3.11 & 2.53 & $x$ & & $x$ \\
\hline $\mathrm{RHOH}$ & 2.23 & 5.39 & 2.42 & $x$ & & \\
\hline ZNF498 & 0.98 & 2.33 & 2.38 & $x$ & & $x$ \\
\hline XP05 & 1.35 & 3.11 & 2.31 & & $x$ & \\
\hline SLC15A3 & 1.07 & 2.45 & 2.28 & & $x$ & \\
\hline TNFRSF4 & 0.95 & 2.09 & 2.19 & $x$ & & $x$ \\
\hline ZNF783 & 1.19 & 2.60 & 2.18 & $x$ & & $x$ \\
\hline$R A B 40 C$ & 1.15 & 2.48 & 2.16 & & $x$ & \\
\hline$S K I$ & 2.03 & 4.19 & 2.07 & $x$ & & $x$ \\
\hline JMY & 2.19 & 4.46 & 2.04 & $x$ & & $x$ \\
\hline
\end{tabular}

Genes selected for immunohistochemistry validation are shown in bold.

AG02-IP, argonaute 2-immunoprecipitated; CD19/BL, ratio of mean immunoprecipitated/total ratio in CD19 to mean immunoprecipitated/total ratio in Burkitt lymphoma; IP/T, mean immunoprecipitated/total ratio.

and lower protein levels of KAT7 in GCB cells consistent with the stronger AGO2-IP enrichment of its transcript in $\mathrm{CD} 9^{+} \mathrm{B}$ cells.

\section{Discussion}

In this study the miRNA targetomes of primary BL cases and normal B cells were identified by AGO2-RIP-Chip. To date, this is the first study focusing on the genome-wide identification of miRNA targets in primary BL tumors, showing the feasibility of performing AGO2-IP on diagnostic frozen tissue samples. Among AGO2-IP-enriched genes in BL, the percentage of predicted targets of the miR17 to 92 cluster was significantly higher compared with all expressed genes and the AGO2-IP-enriched genes in normal B cells. These included some validated targets of miR-17 to 92 (eg, E2F3, ${ }^{34}$ BCL2L11, ${ }^{35}$ FBXW7, ${ }^{36}$ and TGFBR2). ${ }^{37}$ Furthermore, GO and Gene Set Enrichment Analysis showed that miRNA target genes in BL are involved primarily in cell cycle and cell death. Previously, it was shown that the oncogenic miR-17 to 92 cluster is induced by MYC and suppresses apoptosis in BL. ${ }^{27,38,39}$ Although miRNAs of the miR-17 to 92 cluster were recognized as the main oncogenic miRNAs in BL, only a limited number of their target genes relevant for B-cell lymphoma have been identified. ${ }^{40}$ Our results show for the first time the presence of a high number of genes targeted by the miR-17 to 92 cluster members in the miRNA targetome of primary BL tumors and suggest the broad involvement of miRNAs in the regulation of cell cycle and cell death in BL.

Reduced protein levels in BL cases or normal B cells for two of the six selected candidate miRNA target genes, NEDD9 and KAT7, were observed. NEDD9 was validated previously as a target of miR-18 by PAR-CLIP in EpsteinBarr virus - transformed lymphoblastoid B cells. ${ }^{41}$ Decreased mRNA and protein levels of NEDD9 were found in BL compared with normal B cells. NEDD9, alias HEF1 or CASL, is a lymphocyte-specific focal adhesion protein with important functions in B cells. It is essential for activation of the Bcell receptor and $\beta 1$ integrin-mediated signaling pathways in $B$ cells. ${ }^{42,43}$ NEDD9 also is required for the maintenance of marginal zone B cells and trafficking of lymphocytes to peripheral lymphoid organs. ${ }^{44}$ Among genes with higher AGO2-IP enrichment in CD19 ${ }^{+}$B cells, decreased KAT7 protein levels were confirmed in GCB cells in tonsil tissue compared with BL. KAT7, alias HBO1 or MYST2, is a histone acetyltransferase required for histone $\mathrm{H} 4$ acetylation. ${ }^{45}$ Activity of KAT7 is negatively regulated by the tumor-suppressor p53. ${ }^{46}$ Although the possible role of KAT7 in normal B cells or B-cell malignancies is unknown, it is overexpressed in several tumors. ${ }^{45}$

For four of the proteins selected for IHC, the expected expression pattern could not be shown. Potential, more subtle, changes in protein levels, which are hard to show by IHC, might have been missed. Moreover, the overall 
Table 4 IHC Staining of BL Tumors and Tonsil Tissues

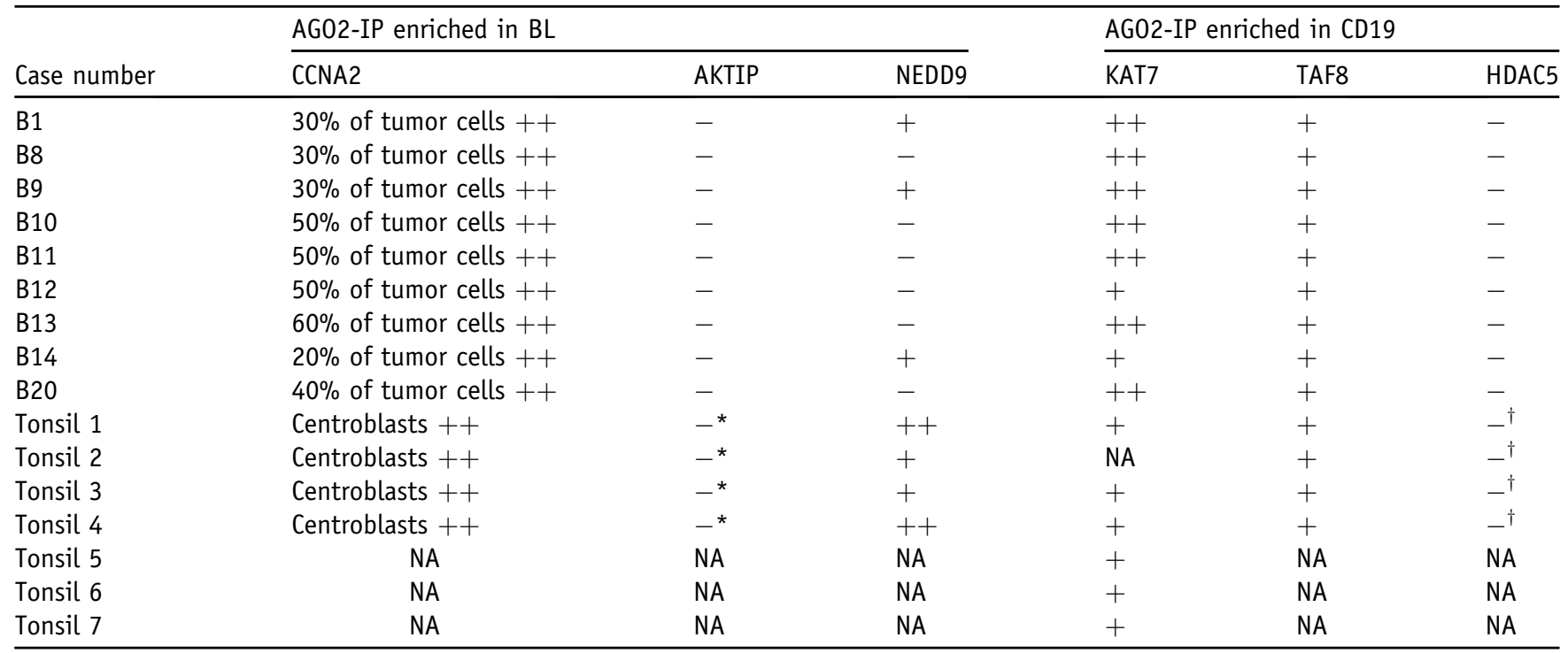

*Macrophages and dendritic cells are positive (+).

${ }^{\dagger}$ Plasma cells within and outside germinal center are strong positive $(++)$.

-, negative; AG02-IP, argonaute 2-immunoprecipitated; BL, Burkitt lymphoma; NA, not used.

outcome of miRNA-mediated repression might be less pronounced owing to differences in mRNA levels and other potential regulatory mechanisms. High-throughput sequencing of RNA isolated by crosslinking immunoprecipitation in the BL cell line Jijoye showed targeting of AKTIP by miR-17/20 and of CCNA2 by miR- $19 .{ }^{47}$ AKTIP was AGO2-IP-enriched in both $\mathrm{BL}$ cases and normal $\mathrm{CD} 19^{+} \mathrm{B}$ cells, albeit more pronounced in BL cases (Figure 3C). Given the moderate mRNA levels of AKTIP, it is possible that it can be repressed efficiently by miRNAs in both $\mathrm{BL}$ and normal $\mathrm{B}$ cells, in agreement with the negative IHC staining. CCNA2, despite being highly AGO2$\mathrm{IP}-$ enriched in $\mathrm{BL}$, also showed AGO2-IP enrichment in two of three $\mathrm{CD} 19^{+} \mathrm{B}$-cell samples (Figure $3 \mathrm{~B}$ ). CCNA2 is highly expressed in both $\mathrm{BL}$ and normal $\mathrm{B}$ cells, which might render its repression by miRNA less efficient, as shown by strong IHC staining in both BL and GCB cells. TAF8 is expressed at much lower levels in CD19 ${ }^{+} \mathrm{B}$ cells as compared with BL, and yet both BL cases and GCB cells showed a similar staining intensity. Despite moderate RNA levels, HDAC5 protein could not be detected by IHC in either BL or GCB cells. It is possible that regulatory mechanisms other than miRNAs may play a role in the case of TAF8 and HDAC5.

Comparison with our previous data ${ }^{12}$ indicated that half of the AGO2-IP-enriched probes in $\mathrm{BL}$ cases were not enriched in cell lines and almost $60 \%$ of the AGO2$\mathrm{IP}-$ enriched probes in cell lines were not enriched in $\mathrm{BL}$ cases. The discrepancies can be explained at least in part by differences in the gene expression profiles of primary tumor tissue and cultured cell lines. Approximately $30 \%$ of the genes that were exclusively AGO2-IP-enriched in primary BL cases were not expressed in BL cell lines and vice versa (data not shown). Another confounding factor may be the admixture of nontumor cells in the BL tumor samples, although tumor cell percentages in BL are typically $>90 \%{ }^{48}$ Finally, cell lines are much more homogenous at the genomic level in general than primary tumors, and this also may lead to differences in miRNA-target interactions. Our results show that some miRNA-target gene interactions may be missed in cell line studies and, conversely, some interactions identified in cell lines may not be present in primary tumors. For example, NEDD9 was AGO2-IP-enriched in primary $\mathrm{BL}$ cases and a lack of NEDD9 protein expression was confirmed in the majority of BL tumor samples, but it was not enriched in the AGO2-IP fraction of BL cell lines.

In this study, BL tissues were compared with $\mathrm{CD} 19^{+} \mathrm{B}$ cells. These sorted B cells contained $23 \%$ to $46 \%$ of GCB cells, which are considered the normal counterparts of BL. The presence of other B-cell subtypes may have confounded our results because it has been shown that miRNA expression profiles differ between B-cell subtypes. ${ }^{49,50}$ Thus, using a mixed population of different B-cell subtypes may have affected the miRNA targetome. However, this approach of bulk B-cell sorting was chosen because it is challenging to obtain high numbers of highly purified GCB cells required for IP of the endogenous $\mathrm{AGO} 2$ protein.

In summary, our study shows that deregulated miRNA expression in BL results in distinct miRNA targetomes of primary BL cases compared with normal B cells. The main processes regulated by miRNAs in $\mathrm{BL}$ are related to cell cycle and cell death. In the light of a limited overlap with the miRNA targetome of BL cell lines, our results underscore the importance of studying the miRNA-target interactions in primary tumor samples. Our study for the 
first time shows the feasibility of performing AGO2-IP on diagnostic frozen tissue samples, offering the advantage of studying miRNA targetomes in primary tumors.

\section{Acknowledgments}

A.D.-K., J.K., K.K., and A.v.d.B. designed and supervised the project; A.D.-K., J.K., B.R., G.K., D.d.J., J.K., M.B., T.v.d.S., and A.S. performed experiments; A.D.-K., J.K., and A.D. analyzed the results; and A.D.-K., J.K., and A.v.d.B., with the help of A.D., L.V., and K.K., prepared the manuscript.

\section{Supplemental Data}

Supplemental material for this article can be found at https://doi.org/10.1016/j.ajpath.2018.01.018.

\section{References}

1. Alexander DD, Mink PJ, Adami HO, Chang ET, Cole P, Mandel JS, Trichopoulos D: The non-Hodgkin lymphomas: a review of the epidemiologic literature. Int J Cancer 2007, 120 Suppl 12:1-39

2. Harris NL, Jaffe ES, Stein H, Banks PM, Chan JK, Cleary ML, Delsol G, De Wolf-Peeters C, Falini B, Gatter KC: A revised European-American classification of lymphoid neoplasms: a proposal from the International Lymphoma Study Group. Blood 1994, 84: $1361-1392$

3. Molyneux EM, Rochford R, Griffin B, Newton R, Jackson G, Menon G, Harrison CJ, Israels T, Bailey S: Burkitt's lymphoma. Lancet 2012, 379:1234-1244

4. Bartel DP: MicroRNAs: genomics, biogenesis, mechanism, and function. Cell 2004, 116:281-297

5. Robertus JL, Kluiver J, Weggemans C, Harms G, Reijmers RM, Swart Y, Kok K, Rosati S, Schuuring E, van Imhoff G, Pals ST, Kluin P, van den Berg A: MiRNA profiling in B non-Hodgkin lymphoma: a MYC-related miRNA profile characterizes Burkitt lymphoma. Br J Haematol 2010, 149:896-899

6. Bueno MJ, Gómez de Cedrón M, Gómez-López G, Pérez de Castro I, Di Lisio L, Montes-Moreno S, Martínez N, Guerrero M, SánchezMartínez R, Santos J, Pisano DG, Piris MA, Fernández-Piqueras J, Malumbres M: Combinatorial effects of microRNAs to suppress the Myc oncogenic pathway. Blood 2011, 117:6255-6266

7. Iqbal J, Shen Y, Huang X, Liu Y, Wake L, Liu C, Deffenbacher K, Lachel CM, Wang C, Rohr J, Guo S, Smith LM, Wright G, Bhagavathi S, Dybkaer K, Fu K, Greiner TC, Vose JM, Jaffe E, Rimsza L, Rosenwald A, Ott G, Delabie J, Campo E, Braziel RM, Cook JR, Tubbs RR, Armitage JO, Weisenburger DD, Staudt LM, Gascoyne RD, McKeithan TW, Chan WC: Global microRNA expression profiling uncovers molecular markers for classification and prognosis in aggressive B-cell lymphoma. Blood 2015, 125: $1137-1145$

8. Schneider C, Setty M, Holmes AB, Maute RL, Leslie CS, Mussolin L, Rosolen A, Dalla-Favera R, Basso K: MicroRNA 28 controls cell proliferation and is down-regulated in B-cell lymphomas. Proc Natl Acad Sci U S A 2014, 111:8185-8190

9. Robaina MC, Mazzoccoli L, Arruda VO, Reis FR, Apa AG, de Rezende LM, Klumb CE: Deregulation of DNMT1, DNMT3B and miR-29s in Burkitt lymphoma suggests novel contribution for disease pathogenesis. Exp Mol Pathol 2015, 98:200-207

10. Slezak-Prochazka I, Kluiver J, de Jong D, Smigielska-Czepiel K, Kortman G, Winkle M, Rutgers B, Koerts J, Visser L, Diepstra A,
Kroesen BJ, van den Berg A: Inhibition of the miR-155 target NIAM phenocopies the growth promoting effect of miR-155 in B-cell lymphoma. Oncotarget 2016, 7:2391-2400

11. Bartolome-Izquierdo N, de Yebenes VG, Alvarez-Prado AF, Mur SM, Lopez Del Olmo JA, Roa S, Vazquez J, Ramiro AR: miR-28 regulates the germinal center reaction and blocks tumor growth in preclinical models of non-Hodgkin lymphoma. Blood 2017, 129:2408-2419

12. Dzikiewicz-Krawczyk A, Kok K, Slezak-Prochazka I, Robertus JL, Bruining J, Tayari MM, Rutgers B, de Jong D, Koerts J, Seitz A, Li J, Tillema B, Guikema JE, Nolte IM, Diepstra A, Visser L, Kluiver J, van den Berg A: ZDHHC11 and ZDHHC11B are critical novel components of the oncogenic MYC-miR-150-MYB network in Burkitt lymphoma. Leukemia 2017, 31:1470-1473

13. Hezaveh K, Kloetgen A, Bernhart SH, Mahapatra KD, Lenze D, Richter J, et al: Alterations of microRNA and microRNA-regulated messenger RNA expression in germinal center B-cell lymphomas determined by integrative sequencing analysis. Haematologica 2016, 101:1380-1389

14. Tan LP, Seinen E, Duns G, de Jong D, Sibon OC, Poppema S, Kroesen BJ, Kok K, van den Berg A: A high throughput experimental approach to identify miRNA targets in human cells. Nucleic Acids Res 2009, 37:e137

15. Swerdlow SH, Campo E, Pileri SA, Harris NL, Stein H, Siebert R, Advani R, Ghielmini M, Salles GA, Zelenetz AD, Jaffe ES: The 2016 revision of the World Health Organization classification of lymphoid neoplasms. Blood 2016, 127:2375-2390

16. Yuan Y, Kluiver J, Koerts J, de Jong D, Rutgers B, Abdul Razak FR, Terpstra M, Plaat BE, Nolte IM, Diepstra A, Visser L, Kok K, van den Berg A: miR-24-3p is overexpressed in Hodgkin lymphoma and protects Hodgkin and Reed-Sternberg cells from apoptosis. Am J Pathol 2017, 187:1343-1355

17. Li J, Kluiver J, Osinga J, Westers H, van Werkhoven MB, Seelen MA, Sijmons RH, van den Berg A, Kok K: Functional studies on primary tubular epithelial cells indicate a tumor suppressor role of SETD2 in clear cell renal cell carcinoma. Neoplasia 2016, 18:339-346

18. Kluiver J, Slezak-Prochazka I, van den Berg A: Studying MicroRNAs in lymphoma. Edited by Küppers R. In Lymphoma: Methods and Protocols. Totowa, NJ: Humana Press, 2013. pp. 265-276

19. Huang da W, Sherman BT, Lempicki RA: Systematic and integrative analysis of large gene lists using DAVID bioinformatics resources. Nat Protoc 2009, 4:44-57

20. Huang da W, Sherman BT, Lempicki RA: Bioinformatics enrichment tools: paths toward the comprehensive functional analysis of large gene lists. Nucleic Acids Res 2009, 37:1-13

21. Subramanian A, Tamayo P, Mootha VK, Mukherjee S, Ebert BL, Gillette MA, Paulovich A, Pomeroy SL, Golub TR, Lander ES, Mesirov JP: Gene set enrichment analysis: a knowledge-based approach for interpreting genome-wide expression profiles. Proc Natl Acad Sci U S A 2005, 102:15545-15550

22. Zhang N, Bevan MJ: Dicer controls CD8+ T-cell activation, migration, and survival. Proc Natl Acad Sci U S A 2010, 107: 21629-21634

23. Selbach M, Schwanhausser B, Thierfelder N, Fang Z, Khanin R, Rajewsky N: Widespread changes in protein synthesis induced by microRNAs. Nature 2008, 455:58-63

24. Martin HC, Wani S, Steptoe AL, Krishnan K, Nones K, Nourbakhsh E, Vlassov A, Grimmond SM, Cloonan N: Imperfect centered miRNA binding sites are common and can mediate repression of target mRNAs. Genome Biol 2014, 15:R51

25. Luo Q, Li X, Li J, Kong X, Zhang J, Chen L, Huang Y, Fang L: MiR$15 \mathrm{a}$ is underexpressed and inhibits the cell cycle by targeting CCNE1 in breast cancer. Int J Oncol 2013, 43:1212-1218

26. Landais S, Landry S, Legault P, Rassart E: Oncogenic potential of the miR-106-363 cluster and its implication in human T-cell leukemia. Cancer Res 2007, 67:5699-5707

27. He L, Thomson JM, Hemann MT, Hernando-Monge E, Mu D, Goodson S, Powers S, Cordon-Cardo C, Lowe SW, Hannon GJ, 
Hammond SM: A microRNA polycistron as a potential human oncogene. Nature 2005, 435:828-833

28. Robaina MC, Faccion RS, Mazzoccoli L, Rezende LMM, Queiroga E, Bacchi CE, Thomas-Tikhonenko A, Klumb CE: miR-1792 cluster components analysis in Burkitt lymphoma: overexpression of miR-17 is associated with poor prognosis. Ann Hematol 2016, 95: $881-891$

29. Zhang X, Chen X, Lin J, Lwin T, Wright G, Moscinski LC, Dalton WS, Seto E, Wright K, Sotomayor E, Tao J: Myc represses miR-15a/miR-16-1 expression through recruitment of HDAC3 in mantle cell and other non-Hodgkin B-cell lymphomas. Oncogene 2012, 31:3002-3008

30. Sander S, Bullinger L, Klapproth K, Fiedler K, Kestler HA, Barth TFE, Möller P, Stilgenbauer S, Pollack JR, Wirth T: MYC stimulates EZH2 expression by repression of its negative regulator miR-26a. Blood 2008, 112:4202-4212

31. Wang M, Yang W, Li M, Li Y: Low expression of miR-150 in pediatric intestinal Burkitt lymphoma. Exp Mol Pathol 2014, 96: $261-266$

32. Kluiver J, Haralambieva E, de Jong D, Blokzijl T, Jacobs S, Kroesen B, Poppema S, van den Berg A: Lack of BIC and microRNA miR-155 expression in primary cases of Burkitt lymphoma. Genes Chromosomes Cancer 2006, 45:147-153

33. Agarwal V, Bell GW, Nam JW, Bartel DP: Predicting effective microRNA target sites in mammalian mRNAs. eLife 2015, 4:e05005

34. Sylvestre Y, De Guire V, Querido E, Mukhopadhyay UK, Bourdeau V, Major F, Ferbeyre G, Chartrand P: An E2F/miR-20a autoregulatory feedback loop. J Biol Chem 2007, 282:2135-2143

35. Mestdagh P, Boström A, Impens F, Fredlund E, Van Peer G, De Antonellis P, von Stedingk K, Ghesquière B, Schulte S, Dews M, Thomas-Tikhonenko A, Schulte JH, Zollo M, Schramm A, Gevaert K, Axelson H, Speleman F, Vandesompele J: The miR-17-92 microRNA cluster regulates multiple components of the TGF- $\beta$ pathway in neuroblastoma. Mol Cell 2010, 40:762-773

36. Olive V, Sabio E, Bennett MJ, De Jong CS, Biton A, McGann JC, Greaney SK, Sodir NM, Zhou AY, Balakrishnan A, Foth M, Luftig MA, Goga A, Speed TP, Xuan Z, Evan GI, Wan Y, Minella AC, He L: A component of the mir-17-92 polycistronic oncomir promotes oncogene-dependent apoptosis. eLife 2013, 2: e00822

37. Dews M, Fox JL, Hultine S, Sundaram P, Wang W, Liu YY, Furth E, Enders GH, El-Deiry W, Schelter JM, Cleary MA, ThomasTikhonenko A: The Myc-miR-17 92 axis blunts TGF $\beta$ signaling and production of multiple TGF $\beta$-dependent antiangiogenic factors. Cancer Res 2010, 70:8233-8246

38. Mu P, Han Y, Betel D, Yao E, Squatrito M, Ogrodowski P, de Stanchina E, D'Andrea A, Sander C, Ventura A: Genetic dissection of the miR-17 92 cluster of microRNAs in Myc-induced B-cell lymphomas. Genes Dev 2009, 23:2806-2811
39. Olive V, Bennett MJ, Walker JC, Ma C, Jiang I, Cordon-Cardo C, Li Q, Lowe SW, Hannon GJ, He L: miR-19 is a key oncogenic component of mir-17-92. Genes Dev 2009, 23:2839-2849

40. Jin HY, Oda H, Lai M, Skalsky RL, Bethel K, Shepherd J, Kang SG, Liu W, Sabouri-Ghomi M, Cullen BR, Rajewsky K, Xiao C: MicroRNA-17 92 plays a causative role in lymphomagenesis by coordinating multiple oncogenic pathways. EMBO J 2013, 32: 2377-2391

41. Skalsky RL, Corcoran DL, Gottwein E, Frank CL, Kang D, Hafner M, Nusbaum JD, Feederle R, Delecluse H, Luftig MA, Tuschl T, Ohler U, Cullen BR: The viral and cellular microRNA targetome in lymphoblastoid cell lines. PLoS Pathog 2012, 8: e1002484

42. Manié SN, Beck ARP, Astier A, Law SF, Canty T, Hirai H, Druker BJ, Avraham H, Haghayeghi N, Sattler M, Salgia R, Griffin JD, Golemis EA, Freedman AS: Involvement of p130Cas and p105HEF1, a novel Cas-like docking protein, in a cytoskeletondependent signaling pathway initiated by ligation of integrin or antigen receptor on human B cells. J Biol Chem 1997, 272:4230-4236

43. Browne CD, Hoefer MM, Chintalapati SK, Cato MH, Wallez Y, Ostertag DV, Pasquale EB, Rickert RC: SHEP1 partners with CasL to promote marginal zone B-cell maturation. Proc Natl Acad Sci U S A 2010, 107:18944-18949

44. Seo S, Asai T, Saito T, Suzuki T, Morishita Y, Nakamoto T, Ichikawa M, Yamamoto G, Kawazu M, Yamagata T, Sakai R, Mitani K, Ogawa S, Kurokawa M, Chiba S, Hirai H: Crk-associated substrate lymphocyte type is required for lymphocyte trafficking and marginal zone B cell maintenance. J Immunol 2005, 175:3492-3501

45. Iizuka M, Takahashi Y, Mizzen CA, Cook RG, Fujita M, Allis CD, Frierson HF, Fukusato T, Smith MM: Histone acetyltransferase Hbo1: catalytic activity, cellular abundance, and links to primary cancers. Gene 2009, 436:108-114

46. Iizuka M, Sarmento OF, Sekiya T, Scrable H, Allis CD, Smith MM: Hbo1 links p53-dependent stress signaling to DNA replication licensing. Mol Cell Biol 2008, 28:140-153

47. Riley KJ, Rabinowitz GS, Yario TA, Luna JM, Darnell RB, Steitz JA: EBV and human microRNAs co-target oncogenic and apoptotic viral and human genes during latency. EMBO J 2012, 31:2207-2221

48. Scott DW, Gascoyne RD: The tumour microenvironment in B cell lymphomas. Nat Rev Cancer 2014, 14:517-534

49. Tan LP, Wang M, Robertus JL, Schakel RN, Gibcus JH, Diepstra A, Harms G, Peh SC, Reijmers RM, Pals ST, Kroesen BJ, Kluin PM, Poppema S, van den Berg A: miRNA profiling of B-cell subsets: specific miRNA profile for germinal center B cells with variation between centroblasts and centrocytes. Lab Invest 2009, 89:708-716

50. Zhang J, Jima DD, Jacobs C, Fischer R, Gottwein E, Huang G, Lugar PL, Lagoo AS, Rizzieri DA, Friedman DR, Weinberg JB, Lipsky PE, Dave SS: Patterns of microRNA expression characterize stages of human B-cell differentiation. Blood 2009, 113:4586-4594 